\title{
Peran Pendamping Desa Dalam Mewujudkan Desa Mandiri
} (Studi Di Desa Karampi Kecamatan Langgudu Kabupaten Bima)

\section{${ }^{1}$ Irfan dan ${ }^{2} \mathrm{M}$. Tahir}

\author{
Program Studi Pendidikan Sosiologi STKIP Bima \\ Jalan Piere Tendean Kel. Mande Tlp.Fax (0374) 42801, Bima 84191, Indonesia \\ email; irfanfagih@gmail.com - tahirbima74@gmail.com
}

\begin{abstract}
Abstrak
Peran pendamping desa adalah mendampingi pemerintah desa dalam perencanaan, pelaksanaan dan pemantauan terhadap pembangunan Desa dan pemberdayaan masyarakat Desa dalam mewujudkan desa mandiri. Penelitian ini tujuannya untuk mendeskripsikan peran pendamping desa dalam mewujudkan desa mandiri. Penelitian ini merupakan penelitian deskriptif kualitatif dengan pendekatan studi riset, yakni mengungkap kejadian nyata dilapangan. Teknik pengumpulan data adalah observasi, wawncara dan dokumentasi. Responden penelitian adalah kepala Desa, pendamping Desa dan sekertaris Desa BPD, ketua Karang Taruna, ketua pemuda. Hasil penelitian dianalisis dengan display data, verifikasi data dan uji keabsahan data lalu kesimpulan. Hasil penelitian ini menunjukan bahwa 1. Peran pendamping Desa di Desa Karampi Kecamatan Langgudu Kabupaten Bima belum efektif karena pendamping Desa tidak melaksanakan fungsing secara terpadu dan bersama-sama dengan pemerintah Desa dalam membangun Desa mandiri, namun keberadaan pendamping Desa hanya sebagai tim survay, pengambilan data untuk kebutuhan pelaporannya, 2. Kendala pendamping Desa dalam melaksanakan peran dan fugsingnya adalah keberadaan jalanan yang dilalui dari Desa yang satu dengan desa yang lain cukup jauh dan jalanan yang dilalui cukup rusak, adanya rasa malas yang tinggiu, kesadaramn bekerja masih kurang, keterbatasan SDM, kedisiplinan kerja yang masih diabaikan, rendahnya tanggungjawab bekerja.
\end{abstract}

Kata Kunci : Peran, Pendamping Desa, Desa Mandiri. 


\section{Pendahuluan}

Pendamping

desa

memiliki

kewenangan penuh untuk mengetahui, melihat dan mengontrol kinerja pemerintah desa berdasarkan Undang Undang, Peraturan Mentri Desa dan segala sesuatu yang mampu memberikan kemandirian terhadap desa tersebut. Adapun tugas dan fungsi pendamping desa dalam menjalankan tugasnya sebagai pendamping ialah mewujudkan desa yang mandiri dari berbagai macam bidang seperti pemberdayaan masyarakat, pembangunan, pengelolaan sumber daya alam (SDA) serta bekerjasama dengan perangkat desa untuk meningkatkan prakarsa, kesadaran, dan partisipasi masyarakat desa dalam pembangunan desa yang partisipatif untuk mewujudkan kemandirian desa tersebut.

Berdasarkan peraturan Menteri Desa Nomor 3 Tahun 2015 tentang pendamping desa, pengertian pendamping desa diartikan sebagai kegiatan untuk melakukan tindakan pemberdayaan masyarakat melalui asistensi, pengorganisasian, pengarahan dan fasilitasi desa (Romzah, 2018). Adanya Pendampingan desa diharapkan mampu mendongkrak perubahan dalam masyarakat desa serta bergerak cepat untuk menyusun strategi dalam menuntaskan kemiskinan dan mengurangi kesenjangan sosial, tentunya sasarannya adalah pembangunan fisik, sarana prasarana desa, pemberdayaan masyarakat dengan tujuan membuka seluas-luasnya terhadap pembangunan desa. Hakikatnya, pendamping desa dibentuk untuk menyelenggarakan urusan pemerintah dan kepentingan masyarakat desa.

Kinerja pendamping desa selama ini ketika mengawal dan menfasilitasi kebutuhan di Desa Karampi masih terbilang minim. Karena hal ini dipicu dengan permasalahan Desa Karampi yang begitu kompleks. Baik mulai dari aparatur, infastruktur, ekonomi dan SDM masyarakat. Pendampingan desa ini tidak akan mampu mengatasi hal tersebut secara langsung, butuh kerjasama seluruh pihak untuk menyelesaikan satu per satu. Selain itu pula, pendamping desa juga tidak hanya mengawal atau mendampingi satu desa saja, melain 3 desa hingga lebih. Hal ini tentunya sangat akan mengganggu konsentrasi para pendamping dalam mengawal desanya dan hal tersebut tidak akan bisa maksimal dan efektif.

Desa Karampi Kecamatan Langgudu Kabupaten Bima sangat memerlukan adanya pendampingan secara khusus dari pendamping desa. karena hal ini pula berkaitan dengan tingkat sumber daya manusia yang dimiliki Desa Karampi. sumber daya manusia di desa ini masih sangat minim, hal ini dibuktikan dengan sedikitnya masyarakat yang berpendidikan 
tinggi. sehingga tidak heran jika pekerjaan yang mereka tekuni ialah sebagai petani. pendamping desa diharapkan mampu meningkatkan kesejahteraan masyarakat pedesaan melalui pemberdayaan masyarakat desa.

Pemberdayaan masyarakat berupaya untuk meningkatkan kualitas sumber daya manusia terutama dalam mem bentuk dan merubah perilaku masyarakat desa untuk mencapai kehidupan yang lebih baik dan taraf hidup yang berkualitas. Oleh karenanya, keberadaan pendamping desa ini diharapkan mampu mengubah desa menjadi lebih maju, aman dan sejahtera. karena mengacu pada tugas utama Pendamping Desa dalam Permendesa No. 3 Tahun 2015 ialah mendampingi desa dalam penyelenggaraan pembangunan 3 tahun lebih agar kinerjanya selalu diopitmalkan untuk kepentingan desa dan masyarakat desa dan pemberdayaan masyarakat desa. kinerja yang aktif dan profesional sangatlah dibutuhkan demi suksesnya sebuah desa.

Namun kenyataan sesuai dengan apa yang peneliti amati selama berada di desa Karampi kecamatan Langgudu kabupaten Bima pendamping desa hanya datang di desa karampi satu atau dua kali setahun dan tidak bekerja sesuai dengan amanat UU yang berlaku maka peneliti juga merasa bahwa pemerintah harusmemberikan ketegasan terhadap pendamping Desa dan melaksanakan evaluasi kerja berdasarkan peraturan menteri desa.

\section{Tinjauan Pustaka}

\section{Efektifitas Peran Pendamping}

Efektivitas peran adalah kepuasan hasil kerja atau perbuatan baik bersifat formal atau tidak yang diperoleh dari target yang direncanakan. Sedangkan pendamping desa adalah sebuah jabatan dibawah naungan kementerian Desa, Pembangunan Daerah Tertinggal Dan Transmigrasi Indonesia, yang ditugaskan untuk mendampingi pemerintah dalam pemberdayaan masyarakat Desa dalam rangka mengimplementasikan UndangUndang No 6 tahun 2014 tentang Desa. Yang dimaksud dengan tenaga pendamping profesional ialah pendamping Desa sebagai mana yang dijelaskan dalam Peraturan Pemerintah Republik Indonesia No 47 Tahun 2015 perubahan atas peraturan pemerintah nomor 43 tahun 2014 tentang peraturan pelaksanaan undang-undang nomor 6 tahun 2014 tentang Desa.Dalam pasal 129 sebagai penjelasan dari pasal 128 ayat (2) yang dimaksud tenaga pendamping profesional adalah :

a. Tenaga pendamping lokal Desa yang bertugas di Desa untuk mendampingi Desa dalam penyelenggaraan Pemerintahan Desa, kerja sama Desa, pengembangan BUM Desa, dan 
pembangunan yang berskala lokal Desa

b. Tenaga pendamping Desa yang bertugas di kecamatan untuk mendampingi Desa dalam penyelenggaraan Pemerintahan Desa, kerja sama Desa, pengembangan BUM Desa, dan pembangunan yang berskala lokal Desa

c. Tenaga pendamping teknis yang bertugas di kecamatan untuk mendampingi Desa dalam pelaksanaan program dan kegiatan sektoral; dan

d. Tenaga ahli pemberdayaan masyarakat yang bertugas meningkatkan kapasitas tenaga pendamping dalam rangka penyelenggaraan Pemerintahan Desa, pelaksanaan pembangunan Desa, pembinaan kemasyarakatan Desa, dan pemberdayaan masyarakat Desa.

Pendamping Desa yang dibantu oleh tenaga ahli infrastruktur dan pemberdayaan menjalankan tugasnya mendampingi pemerintah Desa dalam melaksanakan pembangunan Desa sesuai dengan tuntunan Undang-Undang dan peraturan pemerintah Negara Republik Indonesia (Komaruddin, 2018).

\section{Status Pendamping Desa}

Pendamping Desa adalah tenaga pembantu, yaitu untuk membantu pemerintah dalam melaksanakan tugasnya dalam pembangunan Desa.
Penyelenggaraan pemberdayaan dan pendampingan terhadap masyarakat sejatinya adalah tugas pemerintah sesuai dengan ketentuan UndangUndang yakni Pemerintah dan Pemerintah daerah melakukan pemberdayaan masyarakat Desa dengan pendampingan secara berjenjang sesuai dengan kebutuhan, yang secara teknis dilaksanakan oleh satuan Kerja Prangkat Daerah Kabupaten/atau Kota, dapat dibantu oleh tenaga pendamping professional atau yang disebut dengan pendamping Desa.

Pendamping Desa bukan pegawai negeri ataupun pejabat publik, namun hanya sebagai tenaga kontrak yang ahli dan berkompeten dalam bidang pendampingan dan pemberdayaan yang direkrut oleh Kementrian Desa, Pembangunan Daerah Tertinggal, dan Transmigrasi republik Indonesia untuk ditugaskan membantu pemerintah mendampingi Desa dalam mengimplementasikan Undang-Undang No 6 Tahun 2014 yakni tentang penyelenggaraan dan pembangunan Desa (Komaruddin, 2018).

Status pendamping Desa ialah tenaga kontrak, yaitu pendamping Desa bekerja dengan pemerintah dengan ikatan kontrak kerja yang memiliki jangka waktu yang telah ditentukan. 
Pendamping Desa yang direkrut oleh Kementrian Desa, Pembangunan Daerah Tertinggal dan Transmigrasi Republik Indonesia melakukan kontrak kerja dengan pihak pemberi kerja (pemerintah) melalui Pejabat Pembuat Komitmen (PPK). Artinya, apabila sudah habis masa kontraknya maka tugas seorang pendamping Desa dinyatakan selesai dan telah gugur kewajibanya untuk membantu Desa dampinganya sesuai dengan ketentuan kontrak kerja yang dibuat dan disepakati (Komaruddin, 2018).

\section{Tugas Pendamping Desa}

Tugas pendamping Desa ialah mendampingi dan memberdayakan masyarakat Desa dalam rangka menjalankan pembangunan sesui dengan peraturan kemetrian Desa untuk melaksanakan amanat Undang-Undang Nomor 6 Tahun 2014. Dalam peraturan Kementerian Desa dijelaskan bahwa pendamping Desa mempunyai tujuh tugas pokok yang harus dilaksanakan yaitu :

a. Mendampingi Desa dalam perencanaan, pelaksanaan dan pemantauan terhadap pembangunan Desa dan pemberdayaan masyarakat Desa. Pendamping Desa ditugaskan mendampingi pemerintah Desa mulai dari tahap perencanaan, melaksanakan permusyawaratan Desa bersama masyarakat Desa, kepala Desa beserta aparatur Desa yang bersangkutan, dan dipimpin oleh Badan Permusyawaratan Desa, membuat rancangan pembangunan dan pemberdayaan secara demokratis, menciptakan pembangunan partisipatif, dan melakukan pengawasan secara langsung terhadap proses berjalanya pembangunan dan pemberdayaan masyarakat Desa (Komaruddin, 2018).

b. Mendampingi Desa dalam melaksanakan pengelolaan pelayanan sosial dasar, pengembangan usaha ekonomi Desa, pendayagunaan sumber daya alam dan teknologi tepat guna, pembangunan sarana prasarana Desa, dan pemberdayaan masyarakat Desa. Pendamping Desa, membantu pemerintah dalam meningkatkan pelayanan umum, keaktifan dan ketanggapan pemerintah terhadap permasalahan lingkungan, mengembangkan Badan Usaha Milik Desa (BUM Desa), mengenalkan teklogi kepada masyarakat, memberdayakan masyarakat untuk meningkatkan kualitas sumberdaya manusia, pembangunan infrastruktur sesuai kebutuhan Desa, seperti Kantor Desa, Puskesmas, Balai Desa dan lain-lain. c. Melakukan peningkatan kapasitas 
bagi Pemerintahan Desa, lembaga kemasyarakatan Desa dalam hal pembangunan dan pemberdayaan masyarakat Desa. Pendamping Desa membantu pemerintah Desa dalam melaksanakan tugas kepemerintahan, memberikan ide-ide inofatif untuk menciptakan terobosan-terobosan baru dalam poemerintahan, memberdayakan dan menggali potensi masyarakat serta meningkatkan kreatifitas masyarakat (Komaruddin, 2018).

d. Melakukan pengorganisasian di dalam kelompok-kelompok masyarakat Desa. Pendamping Desa dalam memberdayakan masyarakat di tuntut untuk mengorganizir masyarakat Desa, membina kelompok-kelompok masyarakat seperti, kelompok tani, lembaga swadaya masyarakat, BUM Desa dan Lain-lain.

e. Melakukan peningkatan kapasitas bagi Kader Pemberdayaan Masyarakat Desa dan mendorong terciptanya kader-kader pembangunan Desa yang baru.Melakukan pembinaan, pendidikan dan pengembangan kaderkader pemberdayaan masyarakat Desa baik melalu pelatihan, seminar, dan lain-lain.

f. Mendampingi Desa dalam pembangunan kawasan perDesaan secara partisipatif. Dengan meningkatnya kreatifitas aparatur Desa, dan masyarakat Desa akan menunjang pembangunan kawasa perDesaan yang partisifatif. Keaktifan masyarakat meluli golongan atau kelompokyang terorganizir diharapkan mampu meningkatkan keikutsertaan masyarakat dalam membangun Desanya sendiri.

g. Melakukan koordinasi pendampingan di tingkat kecamatan dan memfasilitasi laporan pelaksanaan pendampingan oleh Camat kepada Pemerintah Daerah Kabupaten/Kota (Komaruddin, 2018).

\section{B. Desa Mandiri}

Kemandirian berarti mengurus dirinya sendiri tanpa bantuan dari orang lain, sedangkan kemandirian desa adalah kewenangan desa dalam mengelola, menata atau bekerja sendiri untuk mewujudkan system pemerintah desa yang mandiri dengan kekuatan lokal, misalnya dengan memanfaatkan sumber daya masyarakat,sumber daya alam dan sumber lain yang akan mendorong pembangun untuk mewujudkan kemandirian desa tersebut. Didalam UU Desa disebutkan ada empat bentuk kewenangan desa, antara lain kewenangan asal-usul, kewenangan lokal berskala 
desa, kewenangan yang ditugaskan oleh pemerintah provinsi, kabupaten/kota, dan kewenangan lain yang ditugaskan oleh pemerintah Provinsi, Kabupaten/Kota. Didit G Suharto, (2016) mengatakan bahwa kemandirian adalah satu sikap yang mengutamakan kemampuan diri sendiri dalam mengatasi berbagai masalah demi mencapai satu tujuan, tanpa menutup diri terhadap perbagai kemungkinan kerja sama yang saling menguntungkan. Konsep mandiri disini pada hakikatnya bukan konsep yang statis dan sempit, yakni tidak sekadar menempatkan kemampuan masyarakat lokal untuk membiayai pembangunan. Konsep mandiri diartikan lebih luas yaitu perimbangan kekuatan antara masyarakat dan pemerintah desa atau desa dengan supradesa (pemerintah diatasnya) dalam menentukan arah dan tujuan perubahan sosial yang terjadi dalam masyarakat atau pemerintahan desa.

Konsep kemandirian desa terakit erat dengan hak otonomi yang dimiliki desa. Otonomi desa yang dikenal sebagai hak untuk menyelenggarakan rumah tangganya sendiri merupakan pernyataan tentang derajat kebebasan didalam pengelolaan sumber daya alam yang bermamfaat dan sumber daya manusia yang ikut serta membangun desa. Artinya pembangunan didesa adalah pembangunan bersama partisipasi masyrakatnya, hal ini juga berlaku dalam pengelolaan BUMDes sebagaimana diatur dalam undang-undang.

C. Kendala Pendamping Desa

Program pendampingan Desa merupakan program yang bertujuan mempercepat pembangunan Desa, karena banyak potensi alam di desa yang masih dikelola secara subsisten, sebagai dampak ketidak-mampuan penguasaan teknologi, pendidikan masyarakat yang relatif rendah serta kecenderungan sifat penduduk desa yang menerima kondisi apa adanya. Namun dalam peranan pendamping Desa memiliki kendala yang dapat memperhambat kemandirian desa antara lain :

1. Keterbatasan SDM

2. Kepedulian kerja yang masih kurang

3. Kedisiplinan kerja yang selalu diabaikan

4. Rendahnya Tanggungjawab

5. Salah paham bahwa pendamping Desa menganggap bahwa tugasnya hanya sekedar survay dan pengumpulan data dan pelaporana

\section{Metodologi Penelitian}

Penelitian ini merupakan penelitian deskriptif kualitatif dengan pendekatan studi riset, yakni mengungkap kejadian nyata dilapangan. Teknik pengumpulan data adalah observasi, wawncara dan dokumentasi. 
Responden penelitian adalah kepala Desa, pendamping Desa dan sekertaris Desa BPD, ketua Karang Taruna, ketua pemuda. Hasil penelitian dianalisis dengan display data, ferifikasi data dan uji keabsahan data lalu kesimpulan.

\section{Hasil Penelitian dan Pembahasan}

\section{Efektifitas Peran Pendamping Desa Karampi Kecamatan Langgudu Kabupaten Bima}

Peran dan fungsi pendamping Desa tidak semuda membalikkan telapak tangan, tetapi terlibat dalam setiap kegiatan Desa mulai dari perencanaan hingga akhir dengan penuh waktu harus didampingi. amanat Undang-Undang Nomor 6 Tahun 2014. Dalam peraturan Kementerian Desa dijelaskan bahwa pendamping Desa mempunyai tujuh tugas pokok yang harus dilaksanakan yakni mendampingi Desa dalam perencanaan, pelaksanaan dan pemantauan terhadap pembangunan Desa dan pemberdayaan masyarakat Desa.

\section{Pendamping Desa ditugaskan} mendampingi pemerintah Desa mulai dari tahap perencanaan, melaksanakan permusyawaratan Desa bersama masyarakat Desa, kepala Desa beserta aparatur Desa yang bersangkutan, dan dipimpin oleh Badan Permusyawaratan Desa, membuat rancangan pembangunan dan pemberdayaan secara demokratis, menciptakan pembangunan partisipatif, dan melakukan pengawasan secara langsung terhadap proses berjalanya pembangunan dan pemberdayaan masyarakat Desa (Komaruddin, 2018).

Selain itu Tugas Pendampingan Desa di atur dalam Peraturan Menteri Desa, PDTT No. 3 Tahun 2015 pasal 12 menyebutkan tugas Pendamping Desa meliputi; pendampingan perencanaan, pelaksanaan dan pemantauan pembangunan Desa; pendampingan pengelolaan pelayanan sosial dasar, usaha ekonomi Desa, sumber daya alam, teknologi tepat guna serta sarana prasarana Desa; pendampingan peningkatan kapasitas perangkat Desa, lembaga kemasyarakatan dan kader pembangunan Desa, pendampingan pengorganisasian kelompok-kelompok masyarakat Desa, pendampingan pembangunan kawasan perdesaan secara partisipatif, serta melakukan pendampingan di tingkat kecamatan untuk berkoordinasi dalam melaporkan pelaksanaan pendampingan.

Dalam hasil penelitian menggambarkan bahwa peran pendamping Desa di wilayah Desa Karampi Kecamatan Langgudu Kabupaten Bima belum efektif karena
a. Pendamping
Desa
kurang berpartisipasi dalam perencanaan, 
melaksanakan permusyawaratan Desa bersama masyarakat Desa, kepala Desa beserta aparatur Desa yang bersangkutan, dan dipimpin oleh Badan Permusyawaratan Desa.

b. Peran pendamping Desa dibutuhkan waktu minimal setiap minggu untuk berpartisipasi dalam masyarakat Desa binaannya, pendamping Desa hanya datang 1 kali dalam 3 bulan untuk mengambil data yang dibutuhkan unruk kelengkapan laporannya.

c. Pendamping Desa dapat dikatakan tidak terlibat membantu pemerintah Desa dalam pembangunan infrastruktur sesuai kebutuhan Desa.

d. Pendamping Desa jarang membantu pemerintah Desa dalam melaksanakan tugas kepemerintahan, memberikanideide inofatif untuk menciptakan terobosan-terobosan baru dalam poemerintahan, bahkan saat rapat, mereka sulit untuk menghadirinya.

Dalam penelitrian ini dapat penulis berikan kesimpiulan bahwa pendamping desa mempunyai peran yang sangat penting dalam pembangunan dan pemberdayaan di desa dan manpu membantu aparatur pemerintahan desa dalam perencanaan, pelaksanaan maupun program pemerintahan di Desa Karampi Kecamatan Langgudu Kabupaten Bima. Peran pendamping Deas mulai dari bidang teknik yang mengurusi urusan teknik dan infrastruktur di Desa dan pendamping desa bidang pemberdayaan masyarakat yang berperan melakukan pemberdayaan masyarakat baik secara langsung maupun melalui pengkaderan dan penguatan lembaga lembaga desa yang ada di Kecamatan Langgudu Kabupaten Bima, karena jumlah pendamping Desa hanya sedikit, maka dibantu oleh pendamping lokal yang berada di desa dan setiap pendamping tidak hanya mendampingi satu desa tetapi mendampingi tiga sampai empat desa, sehingga dengan kurangnya jumlah pendamping desa tersebut menyebabkan fokus pendampingan sesuai dengan peran pendamping desa tersebut kurang maksimal dan kurang efektif.

\section{Kendala pendamping Desa Karampi Kecamatan Langgudu Kabupaten Bima}

Kegiatan apapun yang dihadapi setiap manusia pasti mengalami kendala, Berdasarkan hasil wawancara dan observasi di Desa Karampi diketahui bahwa terkait dengan kegiatan pembangunan desa, masih belum dapat melaksanakan amanat UU tersebut terutama terhadap pendampingan yang dilakukan oleh pendamping lokal desa (PLD), beberapa hambatan Pendamping Lokal Desa (PLD) dalam menjalankan fungsi 
pendampingan Desa diantaranya adalah

a. Kendala pendamping Desa adalah jangkauan Desa yang menjadi binaanya sangat berjauhan dan kondisi jalanan yang menjadi penghubung antara Desa yang satu dengan Desa yang lain cukup rusak sehingga membuat pendamping Desa kurang berpartisipasi dalam kegiatan Desa.

b. Rendahnya Partisipasi Masyarakat karena pada umumnya masih belum secara partisipatif, dimana dalam perencanaannya hanya dilakukan oleh pemerintahan desa, baik dilaksanakan sendiri oleh kepala desa, aparat desa, dan BPD, maupun dilakukan oleh orang yang menjadi konsultan dalam perencanaan pembangunan desa. Namun sejak bebarapa tahun terakhir sudah melibatkan masyarakat dalam melaksanakan perencanaan melalui mekanisme musrenbangdes, walaupun belum maksimal.

c. Sejak adanya pendampingan yang dilakukan oleh pendamping desa, sudah banyak kemajuan, diantaranya melalui musyawarah perencanaan pembangunan desa (Musrenbangdes).

Pernyataan tersebut menunjukan bahwa konsep pembangunan desa telah menempatkan perlakuan terhadap masyarakat dalam pembangunan pada posisi yang begitu berarti dan sentral, Sehingga keterlibatannya dalam proses pembangunan menjadi titik penentu apakah proses pembangunan itu menjadi wahana proses belajar atau hanya sekedar sebuah rekayasa yang mana pemerintah menjadi pemain tunggal. Dengan demikian penekanan pada aspek "proses" memiliki arti penting. Proses belajar mengandung makna bahwa setiap kekurangan dan kelemahan yang muncul dalam proses pelaksanaan program pembangunan menjadi informasi yang penting dan untuk itu dilakukan upayaupaya penanggulangannya. Selanjutnya beliau menambahkan: "Namun sayangnya, belum semua komponen masyarakat diundang dalam kegiatan tersebut. Pada umumnya yang diundang dalam musrenbangdes adalah tokoh-tokoh masyarakat saja.

d. Masyarakat Desa belum bisa melakukan kerjasama dan kolaborasi dengan pemerintah Desa, organisasi pemuda untuk berbagi 
dalam memberikan ide-ide demi kelancaran kegiatan pemuda, karena kurangnya pemahaman pendamping Desa dalam menjalankan fungsi pendampingan pada proses penyusunan dokumen perencanaan seperti kurangnya kemampuan teknis perencanaan pembangunan desa, tercermin dari dokumendokumen perencanaan desa yang belum lengkap.

e. Kepedulian dan kesadaran kerja pendamping Desa yang masih minim karena Setiap pekerjaan dan mendapatkan hasil yang baik, harus memiliki kesadaran dan tanggungjawab serta peduli terhadap dampak yang terjadi, apabila tidak dilakukan secara profesional. Selain itu keterbatasan SDM, Kepedulian kerja yang masih kurang, Kedisiplinan kerja yang selalu diabaikan, Rendahnya rasa Tanggungjawab dalam bekerja.

\section{Kesimpulan}

Dalam penelitrian ini dapat penulis berikan kesimpiulan bahwa pendamping desa mempunyai peran yang sangat penting dalam pembangunan dan pemberdayaan di desa dan manpu membantu aparatur pemerintahan desa dalam perencanaan, pelaksanaan maupun program pemerintahan di Desa Karampi Kecamatan Langgudu Kabupaten Bima. Peran pendamping Deas mulai dari bidang teknik yang mengurusi urusan teknik dan infrastruktur di Desa dan pendamping desa bidang pemberdayaan masyarakat yang berperan melakukan pemberdayaan masyarakat baik secara langsung maupun melalui pengkaderan dan penguatan lembaga lembaga desa yang ada di Kecamatan Langgudu Kabupaten Bima, karena jumlah pendamping Desa hanya sedikit, maka dibantu oleh pendamping lokal yang berada di desa dan setiap pendamping tidak hanya mendampingi satu desa tetapi mendampingi tiga sampai empat desa, sehingga dengan kurangnya jumlah pendamping desa tersebut menyebabkan fokus pendampingan sesuai dengan peran pendamping desa tersebut kurang maksimal dan kurang efektif.

\section{Sedangkan kendala pendamping Desa} adalah jangkauan Desa yang menjadi binaanya sangat berjauhan dan kondisi jalanan yang menjadi penghubung antara Desa yang satu dengan Desa yang lain cukup rusak sehingga membuat pendamping Desa kurang berpartisipasi dalam kegiatan Desa. Kemudian pendamping Desa belum bisa melakukan kerjasama dan kolaborasi dengan pemerintah Desa, organisasi pemuda untuk berbagi dalam memberikan ide-ide demi kelancaran kegiatan pemuda, karena kurangnya kepedulian dan kesadaran kerja 
pendamping Desa yang masih minim karena

Setiap pekerjaan dan mendapatkan hasil yang baik, harus memiliki kesadaran dan tanggungjawab serta peduli terhadap dampak yang terjadi, apabila tidak dilakukan secara profesional. Selain itu keterbatasan SDM, Kepedulian kerja yang masih kurang, Kedisiplinan kerja yang selalu diabaikan, Rendahnya rasa Tanggungjawab dalam bekerja.

\section{Daftar Pustaka}

Dwi A Lestari, 2019. Peran Pendamping Desa Dalam Mewujudkan Kemandirian Desa (Studi Desa Serang, Kecamatan Karangreja, Kabupaten Purbalingga). Skripsi. Program Studi Pengembangan Masyarakat Islam Jurusan Pengembangan Masyarakat Fakultas Dakwah Institut Agama Islam Negeri Purwokerto

Didik G. Suharto, 2016. Membangun Kemandirian Desa. Yogyakarta: Pustaka Pelajar

Peraturan Pemerintah Republik Indonesia Nomor 47 Tahun 2015 Perubahan Atas Peraturan Pemerintah Nomor 43 Tahun 2014 Tentang Peraturan Pelaksanaan Undang-Undang Nomor 6 Tahun 2014 Tentang Desa

Didik G. Suharto, 2016. Membangun Kemandirian Desa. Yogyakarta: Pustaka Pelajar

Adriansyah. 2018. Fungsi Badan Pemusyawaratan Desa (BPD) Dalam Pengawasan Desa (Study pada Pemerintah Desa Kuala Lapang Kecamatan Malinau Barat Kabupaten Malinau). Gelar Magister Ilmu

$\begin{array}{lcr}\text { Administrasi } & \text { Bidang } & \text { Minat } \\ \text { Administrasi } & \text { Publik. } & \text { Program } \\ \text { Pascasarjana } & \text { Universitas } & \text { Terbuka. } \\ \text { Jakarta } & & \end{array}$

Christina. M. 2017. Kinerja Pendamping Lokal Desa Dalam Peningkatan Pembangunan Desa Di Kecamatan Kalirejo Kabupaten Lampung Tengah. Skripsi. Fakultas Ilmu Sosial Dan Ilmu Politik Universitas Lampung.

Komaruddin. 2018. Peran Pendamping Desa Dalam Pemberdayaan Masyarakat (Studi Di Pekon Paku Kecamatan Kelumbayan Kabupaten Tanggamus). Gelar Sarjana Sosial (S.Sos) Dalam Bidang Ilmu Ushuluddin. Fakultas Ushuluddin Universitas Islam Negeri Raden Intan. Lampung

Romzah. S. 2018. Optimalisasi Fungsi Pendamping Lokal Desa Dalam Pembangunan Desa Sukorejo Dan Karanganom, Kecamatan Karangbinangun, Kabupaten Lamongan. Gelar Sarjana Strata Satu (S-1) dalam Ilmu Ushuluddin dan Filsafat. Fakultas Ushuluddin Dan Filsafat Universitas Islam Negeri Sunan Ampel. Surabaya.

Watiah. M. 2011. Efektivitas Pembinaan Dinas Pengelolaan Pasar Terhadap Pedagang Kaki Lima Di Kota Bandar Lampung (Studi Pada Pasar Bambu Kuning Kota Bandar Lampung). Fakultas Ilmu Sosial Dan Ilmu Politik Universitas Lampung. Bandar Lampung.

Wiwin. 2017. Peran Badan Permusyawaratan Desa (BPD) Dalam Pembangunan Di Desa Salassae Kecamatan Bulukumpa Kabupaten Bulukumba. Untuk Memenuhi Sebagian Persyaratan untuk Mencapai Derajat Sarjana S-1. Fakultas Ilmu Sosial Dan Ilmu Politik Universitas Hasanuddin Makassar. Makasar. 